\title{
11 \\ Politics, Picnics and Playing Fields: Lime Kiln Bay
}

The campaigns around the bays along the Georges River from Lime Kiln Bay to Gungah Bay in Oatley West were different from the fishing community orientation of the Great Moon Bay dispute. The Lime Kiln Bay resident campaigners did call on expert advice in their conflict with Hurstville Council, just like others. Overall, however, they used two main strategies. First, they undertook energetic outreach through word of mouth and community groups of all sorts, including church groups, to build up persuasive demonstrations of community support with which to force Hurstville Council to concede. Second, they mobilised political networks very early by calling on state and federal Australian Labor Party (ALP) politicians and later by intervening in local government elections.

The campaigners were people from many different occupations, including teachers, but much of their cohesion arose from the wide support for the secular local West Oatley Progress Association and a background of working-class solidarity exemplified by the working and community activist life of Mick Staples, even though he had passed away before the main campaign began. Just as important as Mick, however, was his wife, Ruth, from the Haworth family. Ruth had grown up in Seaforth Avenue, which, in her childhood in the 1930s, was little more than a dirt track. But it had a view of the Dairy Creek, which ran through swampland before reaching Lime Kiln Bay. When Ruth married Mick, they bought a house on Dame Mary Gilmore Road, just 500 metres further downstream and closer to Lime Kiln Bay. Between Ruth's two homes - and even closer to 
the creek and swamp - Don McMinn lived most of his life. All three of them knew each other well - and they knew that waterway, its plants and its wildlife, just as well as they knew each other.

Don talked about it in 2002 to a neighbour, David Waterhouse, remembering that there had been few mangroves on Lime Kiln Bay swampland at all until the end of World War II, when he believed that clearing for subdivisions upstream had increased the siltation and allowed the mangroves to expand. Don recalled many animals and plants along the river, and spoke particularly about the birds, which he knew from the swamp and creek as well as his family aviary. Waterhouse recorded Don telling him that:

Wild ducks, ibis and spoonbills did not occur then as now, but Red-eyed Tree Frogs bred after rain and Stubble Quail called from the grass and could be heard on still evenings. Yellow-tufted and New Holland Honeyeaters nested in the shrubs. Peewees by the hundred flocked to roost. Whipbirds, Double-barred Finches and Rufous Whistlers were common and Wood-swallows and Jacky Winters nested each year in the few tall trees. None of these birds occur locally today. ${ }^{1}$

The campaigners who tried to save Dairy Creek and the bushland around it were people like Mick and Ruth and Don, as well as their newer neighbours, like Dave and Tricia Koffel. Eventually, when their petitions and meetings failed to move the council, the activists took up campaigning in the local government elections in 1974. Their motivations, exemplified by those of Ruth Staples, stressed the value of natural bushland, including the mangroves, to allow informal 'passive' recreation rather than the intrusive competitive discipline of organised sports. Yet there was interest too, as Dave Koffel's memories show, in the ecological networks of the area, and widespread commitment to protecting local people's access to this rich local resource. But we can start the story from earlier on.

\section{Lime Kiln Bay}

Lime Kiln Bay lies to the east of Salt Pan Creek, with three tributaries running into it. On the western side, Boggywell Creek had had riverbed sand and mud dumped on it several times in the 1930s to 'reclaim' it as

1 Waterhouse, 'Lime Kiln Bay', 1. 
Gannons Park. There had been a further 1930s plan to utilise relief workers to fill in more of the remaining reaches, over the central one of which a golf course had been partially built while Dairy Creek continued to flow in from the east. But such plans had been overtaken by war and had not been considered until, in 1964, residents began to hear that council hoped to reactivate the proposed tip in the west (north) arm. A vocal opponent of such plans had been the West Oatley Progress Association - in which Mick Staples and Don McMinn were involved.

Mick Staples was a printer and an outspoken unionist who took a strongly activist role in community protest over damage to the river. As technological change had reorganised the printing trade, Staples had taken work at Fisher Library but had also begun writing. He published Paddo in $1964 .{ }^{2}$ His long commitment to the local environment had many repercussions, even though he died suddenly in 1970. He had become close friends with Don McMinn, who knew the river and its wildlife so well. ${ }^{3}$ McMinn recalled that the Progress Association had been active in pushing for the damage to the river to be addressed, remembering:

My neighbour, Mick Staples, agreed that the place was going to blazes and more needed to be done. He had heard of the conservation meeting at Rafe and Moyia Kowron's place and he suggested we go along. We were in anything but a bath in those days! The feeling was that we would do anything to save Oatley. ${ }^{4}$

Staples's nephew, Robert Haworth, has recalled that, in the 1940s:

The wetlands offered the natural 'adventure playground' that real bush and swamp give, or even exotic weeds like lantana, as opposed to the truck tyre 'adventure playgrounds' that some councils spend a fortune on today. The big attraction of the Lime Kiln Bay swamp for kids over generations was not just the mangroves, but the huge reed swamps of canegrass, looking like the scenery in the 'African Queen' adventure movie of the 1950s. ${ }^{5}$

2 Using his given name, Arthur Staples, published by Ure Smith.

3 David Waterhouse interviewed Don in 2002, and reported Don's rich environmental memories in Waterhouse, 'Lime Kiln Bay', 1.

4 Fairley, Being Green, Ch. 2.

5 Robert Haworth, pers. comm., June 2020. Lantana is an exotic and invasive plant, understood as a weed. Swamp canegrass, Eragrostis australasica, is a native, saline-tolerant tussock grass. 
Council applied to the state government for permission to reclaim the two remaining upper reaches of Lime Kiln Bay in February 1967, proposing to build a causeway to cut across from Oatley Park to Lorraine Street, Peakhurst, cutting off both the north and easterly arms of the bay so they could be 'reclaimed' by rooting out the existing mangroves, swamp and bush, levelling it and filling the space with rubbish. ${ }^{6}$ This was to take some years of active dumping but eventually would extend the existing golf course and allow for the building of a new playing field.

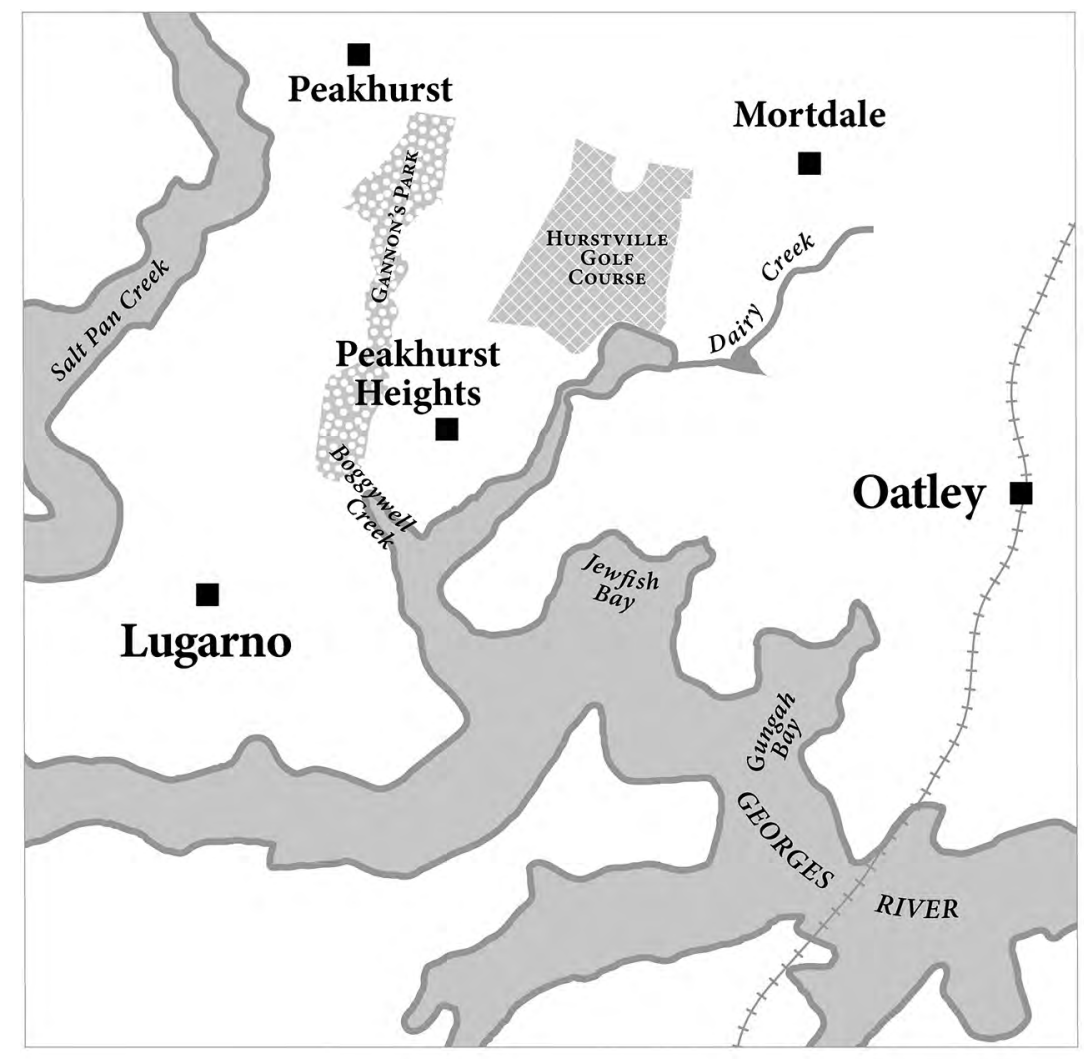

1 kilometre

Map 11.1: Lime Kiln Bay and neighbouring waterways.

Cartography: Sharon Harrup.

6 For the impact of such levelling, see Figures 7.2 and 7.4, this volume. 

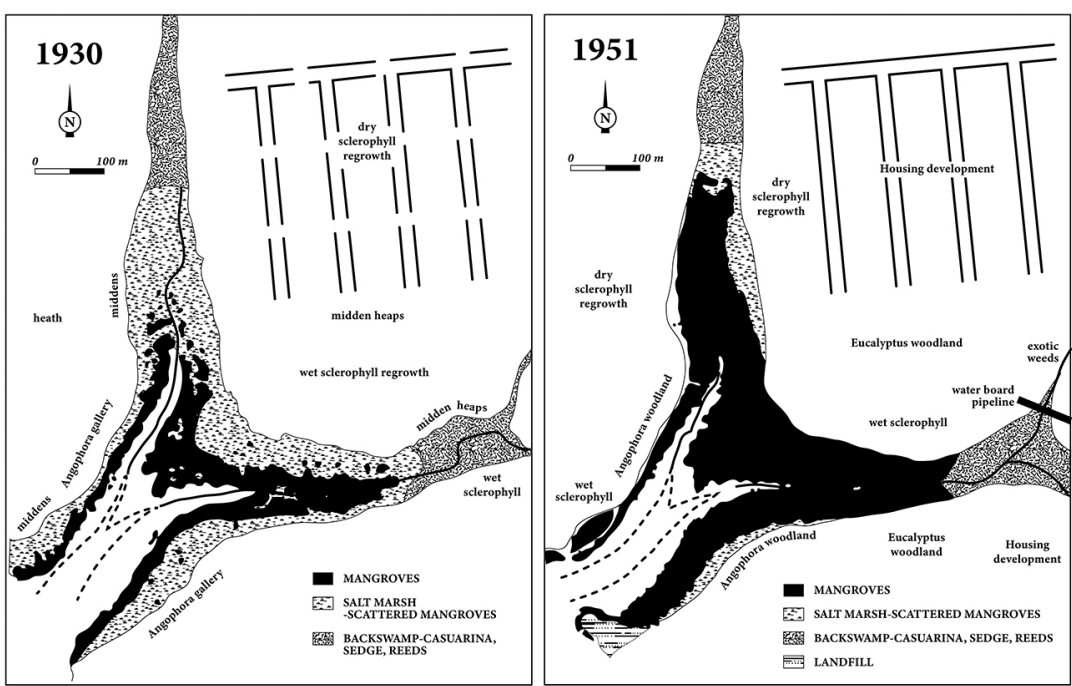

Map 11.2: Mangrove expansion at Lime Kiln Bay.

These drawings were derived from Defence Force aerial photographs taken in 1930 and 1951, drawn initially by geographer Robert Haworth, for his 2003 paper 'Changes in Mangrove/Salt Marsh Distribution'. As Haworth showed, the aerial photos confirm Don McMinn's memories that mangrove expansion had occurred after 1930. Maps redrawn for this volume with permission by Sharon Harrup, cartographer.

The Oatley Flora and Fauna Society (OFF) had been formed further downstream as a self-education body, but a number of people living around Lime Kiln Bay had become members by the mid-1960s. Rumours had begun to circulate by early 1968 that Hurstville Council was planning to undertake 'reclamation' by dumping rubbish for landfill. Some members of OFF wrote to the local press in September 1968 expressing fears that this would lead to a loss of 'mangrove swamp at Lime Kiln Bay', which was habitat for native fauna and provided an educational resource. ${ }^{7}$ These concerned local residents wrote as well to the Department of Education and the chief secretary to propose using the site as a special study area for schools and for the conservation of fish stock in the Georges River. ${ }^{8}$ By December 1968, barely a month after his earlier intervention over Great Moon Bay, Chief Secretary Eric Willis acted again, writing to inform OFF that he would not be approving the reclamation application because:

7 See letter to St George and Sutherland Shire Leader (hereafter Leader), 25 September 1968, 2.

8 'Oatley Park', OFF News, October 1968, 2. 
[As] the area is a nursery for fish, disruption of the mangroves would accelerate siltation which would affect the tidal storage of the river, and increased turbidity would endanger the adjacent oyster leases. ${ }^{?}$

OFF agreed that it was important to preserve the saline swamp in its natural state as a feeding ground for birds and fish and as study area for school children, and so it invited Allen Strom to become involved. A former teacher, Strom was a bushwalker and environmental activist who had grown up around Belmore and spent much of his adolescence in Mill Creek, a tributary of the Georges River running in from the south, nearly opposite Salt Pan Creek. From as early as 1958, Strom had been speaking at OFF meetings. ${ }^{10}$ Previously an officer in the National Parks and Wildlife Service, he had recently become the environmental education officer to the Department of Education. Strom was a lifelong advocate of 'citizenbased nature conservation movements' and he strongly supported local 'citizen fighters for conservation' like the members of OFF. He advised them to stress to the council that mangroves were crucially important to the river's ecology. ${ }^{11}$ Then, through the Department of Education, Strom wrote to Hurstville Council requesting that it keep Lime Kiln Bay as a 'special study area for schools', but the council rejected the request in March 1969. ${ }^{12}$ Nevertheless, OFF continued to ask questions and referred the matter to Senator Tony Mulvihill, to be followed up in the Senate Select Committee on Water Pollution in which he was taking a vocal role. ${ }^{13}$

By July 1969, a petition had been organised by one of the concerned local residents, Arnold Bryden, to protest against:

The reclamation of the Lime Kiln Bay swamp area in Oatley West with the dumping of rubbish and filling. We understand from information supplied by the NSW Department of Fisheries that this area supplies food and protection to a very large number of fish during part of their life cycle. The loss of this habitat will only result in a considerable decrease in the fish population. Also that

9 'Oatley Park - Limekiln Bay', OFF News, January 1969, 3.

10 Fairley, Being Green; Fox, Chief Guardian, Ch. 2.

11 Fox, Chief Guardian, Ch. 2.

12 'Oatley Park', OFF News, April 1969, 4.

13 Ibid.; Fox, Chief Guardian, Ch. 11. 
the swamp helps to prevent silting of the Georges River. A large number of native birds make use of the area and it provides a study area for local schools. ${ }^{14}$

Council agreed to a meeting with Mrs Ida Carder (then secretary of OFF) and officers of New South Wales Fisheries and Health departments. The compromise apparently reached was that council would reduce the original area it had planned to fill to only the upper part of the north (western) arm of the bay. Fisheries had imposed stringent conditions on the project, approving filling only to the high-water mark even on that arm, and eventually OFF had agreed - unhappily - to the compromise. ${ }^{15}$ There the matter rested uneasily. The council began filling the upper reaches of the north arm, but the eastern arm, Dairy Creek, appeared to be untouched.

Then, unexpectedly, in later 1973, Hurstville Council reactivated its intention to dump rubbish in the eastern arm of the bay and moved swiftly to begin work. In October, Lewis Staples (Mick Staples's son) discovered survey pegs staked out across the upper bay. Mick had already passed away, but his commitment to community activism was shared by his family, in particular, by his widow, Ruth, who had grown up loving the area and valuing the possibilities the bush offered for picnics and social gatherings in natural settings.

It was extremely rare for women to take public roles in these Georges River campaigns. At Hunters Hill, the 'Battlers for Kelly's Bush' who approached the Builders Labourers' Federation (BLF) were all women, but on the Georges River this was not the case. This was not because women were not involved. From the earliest campaign in the 1950s for the national park, women took many supporting roles. Minnie Jacobsen, Eileen Stills, Esme Clisby and Eileen Birch, along with many other women, all took part in the fundraising, the networking and the meetings. Yet none of them ever spoke in public to represent it. ${ }^{16}$ Again, downstream

14 Content of petition and sketch of proposed reclamation held by David Koffel, secretary, in Lime Kiln Bay Preservation Committee Archive, David Koffel Collection (hereafter LKBPC Archive), and partly reproduced in Fairley, Being Green. Fairley notes that Arnold Bryden organised this 1969 petition. Koffel remembered that it was Phyl and Arnold Bryden, with their deep knowledge of the local environment, who were crucial to his rapid education in ecology when he became involved in the next wave of activism to save Lime Kiln Bay in 1973. Mick Curlisa, then mayor of Hurstville Council, had been source of information for sketch.

15 David Koffel notes, 2005, LKBPC Archive; Fairley, Being Green.

16 Alf and Eileen Stills and Carol Jacobsen, interview; PPRA, interview; Carol, Colin and Kevin Jacobsen, interview, 12 July 2006. 
in the campaigning to save Poulton Creek and surrounding bush, women were important in the initiation of activities as well as in building and maintaining connections between disparate participants. ${ }^{17}$ Yet it was only in this Lime Kiln Bay campaign that a woman became visible. Ruth's decision to become a public spokesperson demonstrates the level of her concern but also suggests her courage and conviction.

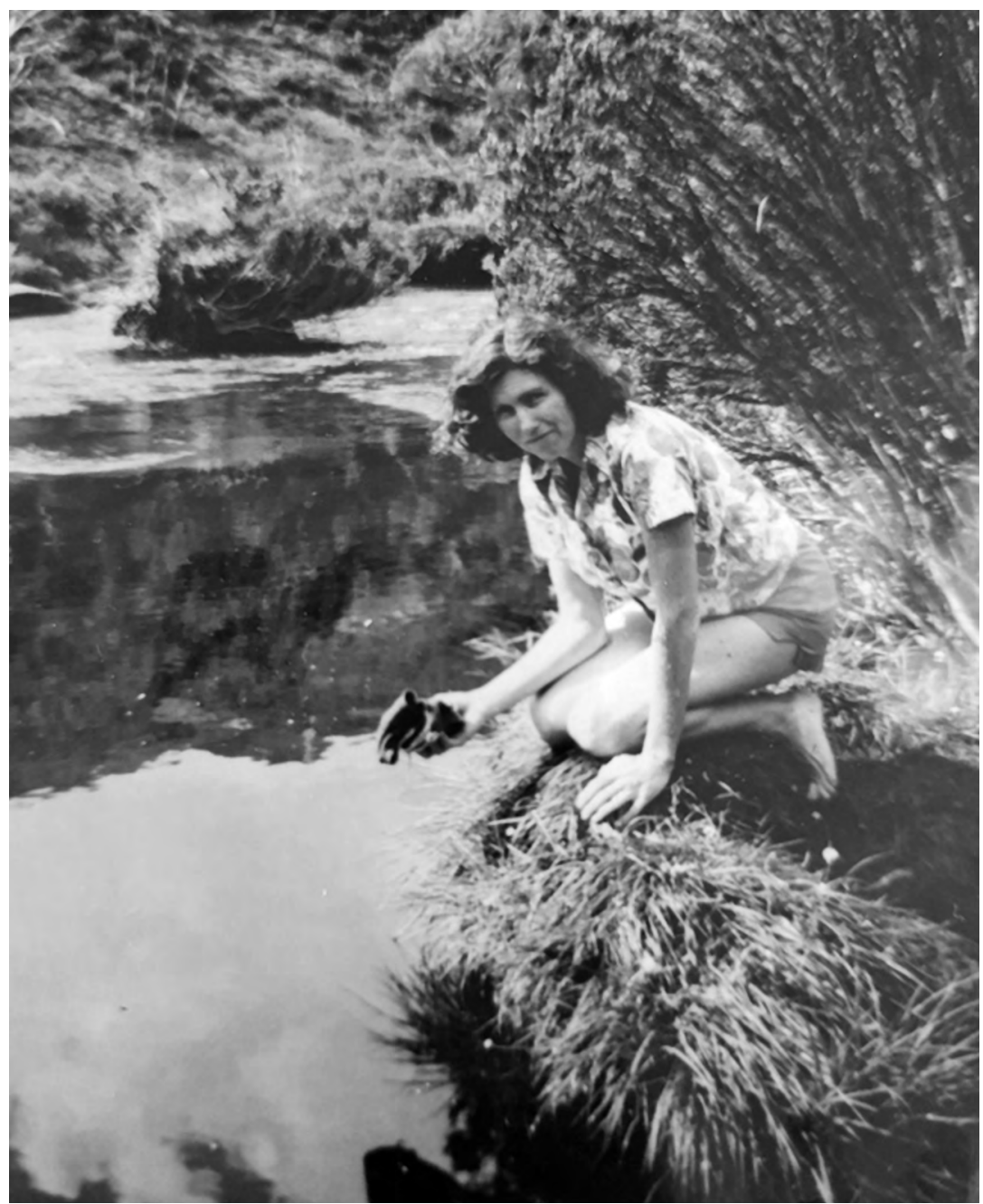

Figure 11.1: Ruth Staples at Thredbo, 1966.

Photograph by Mick Staples, Ruth's husband, while on a family holiday. Courtesy of the Haworth family collection.

17 See Chapter 12, this volume. 
Ruth and her teenage son, Lewis, raised this sudden council activity with their new neighbours, Dave and Tricia Koffel, both schoolteachers, who had recently moved from Bankstown. David, a secondary teacher, was an active member of the ALP. ${ }^{18}$ At university and teachers' college, Dave had taken part in the opposition to the Vietnam War, meeting Bill White, the unassuming primary teacher who, in 1966, had become Australia's first conscientious objector (see Chapter 8). Since moving to Lime Kiln Bay, Dave had taught at Hurstville High School, where Lewis and other young local people studied. While they all objected to the threat of further rubbish on their doorstep, both the Staples and Koffel families valued the bushland they lived near and were angered that it was going to be eroded even further. Together they formed a new organisation, the Lime Kiln Bay Preservation Committee (LKBPC), with Dave as secretary, and began to collect supporters. They called on the State Pollution Control Commission for support - with little response - and went to the press for coverage, with both Lewis Staples and his sister Caroline speaking to television reporters. ${ }^{19}$ By 9 January 1974, the LKBPC had Frank Walker and Pat Rogan inspecting the 'filthy mess' of the river and, barely a month later, on 6 February, the Opposition leader Neville Wran had announced that the pollution of the Georges River would set the Labor Party agenda for the next New South Wales election. ${ }^{20}$

The council's reaction to them was vitriolic. Dave has recalled that key councillors believed that anyone who was progressive must be a communist and so they had no hesitation in declaring to the local press 'that we were communists defending a mosquito-ridden swamp'. Dave admitted: 'It's very nasty when you read that sort of stuff in the papers! But at no stage did I anticipate how personally unpleasant it would become'. He reflected ruefully about the small group of campaigners who 'began this tilt at a windmill'. ${ }^{21}$

And yet, despite their small numbers, they found rapid support among fellow residents. Dave learnt much from Phyl and Arnold Bryden, who insisted that commitment was not enough without knowledge of the natural environment being defended. The Brydens were both interested in birdlife, just like Mick Staples's old friend, Don McMinn, but Dave

18 Mitchell, Teachers, Education, and Politics.

19 Staples, interview, 27 May 2005. No archival TV footage has been located.

20 'River's a "Filthy Mess"', St George Pictorial, 9 January, 1974, 1; 'River Vote Angle' and 'River

Sets Labor's Strategy: Pollution is a Vote Clincher', St George Pictorial, 6 February 1974, 1, 3.

21 Koffel, interview. 
does not recall that interest in birds to have dominated over concern for other parts of the environment. The Brydens talked to Dave about the important role of mangroves in river ecology and gave him an armful of reading about estuarine environments.

The mangroves were the most identified form of vegetation in the LKBPC documents and press coverage of the debates, the terms 'mangroves' and 'mangrove swamp' being used to refer to the whole wetland complex - the mangrove species and the saltmarsh, all regularly inundated and waterlogged. In its very first press release in December 1973, for example, the committee referred in general terms to the vegetation and fauna that would be destroyed by a tip but referred by name only to mangroves. ${ }^{22}$ The committee cited the recent Australian Conservation Foundation (ACF) statement that mangroves were of 'national importance' because of their high productivity and as key elements in the long-term maintenance of the coastal environment. The LKBPC built on this ACF statement to argue: 'We just cannot go on forever tipping into our rivers and estuaries. No mangrove area is safe anymore'. ${ }^{23}$ In its third press release it stated:

Lime Kiln Bay Preservation Committee has attacked the plan [for the tip] which would mean the destruction of hundreds of square yards of mangroves, and the destruction of natural bushland. Natural bushland would be destroyed at a time when such areas are rapidly disappearing from Sydney. ${ }^{24}$

This pattern was repeated throughout all the LKBPC's letters and press releases for 1974, with mangroves being the only vegetation specified among the more generalised references to 'bushland' and 'natural vegetation'. Their letters often referred to the support they had received from state and federal parliamentarians, like the ALP member for Barton and former teacher, Len Reynolds. ${ }^{25}$ The people actually involved in these campaigns, however, were local residents in the Lime Kiln Bay and the nearby Oatley West areas. Most of the Lime Kiln Bay activists and supporters were not involved with OFF or other conservation groups and were probably more diverse than OFF papers suggest. Some in the Lime Kiln Bay organisation were tradespeople, union activists and housewives while others were teachers. In this area, the Progress Association was seen

22 LKBPC to HMC, 10 January 1974, Press Release 2, 14 January 1974, LKBPC Archive.

23 LKBPC, Press Release 1, December 1973, LKBPC Archive.

24 LKBPC Press Release 3, undated, LKBPC Archive.

25 LKBPC Press Release 4, undated, LKBPC Archive. 
as an activist and radical body. Ruth Staples was retraining as a teacher, but the area continued in 1974 to be home to a significant proportion of workers. Ruth's father had been a waterside worker and a member of the Communist Party of Australia. Many other men around the Bankstown and Peakhurst area were railway workers, just as Senator Tony Mulvihill had been, employed at the Chullora railway workshops - and with a corresponding orientation to working-class politics. Dave Koffel was a university-trained secondary teacher but had grown up in Bankstown where his mother told him about her childhood in Broken Hill as the daughter of a miner and strong union activist. Dave himself was an active ALP member and was able to draw in continuing support from local ALP state and federal representatives throughout this campaign.

Ruth's and Dave's motives for involvement suggest the range of concerns in suburban environmental activism. In remembering the main issues, neither activist raised sewage or industrial pollution, but the LKBPC most definitely saw this as a problem. It had been of concern in the Lime Kiln Bay dispute but the LKBPC also took a stand on the Poulton Park conflict in relation to Oatley Bay, where it argued strongly that Hurstville and Kogarah councils' plans would exacerbate the problems of sewage flow into the bay by obstructing tidal flows, thus limiting the capacity of the estuary to clean itself. ${ }^{26}$ But, as Ruth and Dave recorded in their interviews, it was the issue of garbage and the impact its disposal would have on the destruction of swamps and natural bush that primarily concerned them both. They were each certainly worried about the aesthetic and health implications of a rubbish tip so close to their homes on the edge of the Creek Reserve, which would make this a simple 'NIMBY' (not in my backyard) issue, but their memories of their motives for involvement went much further.

For the rest of her life, although Ruth remained deeply interested in the vegetation and ecology of the creek, she was just as concerned that opportunities for informal social interactions - picnics and leisure time - spent in natural surroundings would be lost if the bush was converted to playing fields or golf course fairways. ${ }^{27}$ Whatever the touted benefits of competitive sports, Ruth did not believe they offered either relaxation or restoration; nor did they provide opportunities for socialising with friends or relations, which she saw as central to community life. She was deeply 
suspicious of the coercive nature of organised sports - suspicious precisely about the discipline that authorities hoped would be beneficially imposed on working-class youth.

In his interviews, Dave focused instead on the intricacies of creek ecology. He had embraced the biological knowledge he gained from Phyl and Arnold Bryden and had begun exploring the interdependencies between species that ecological science opened for him. As a higher degree student in later years, he became an avid birdwatcher, a pursuit that now leads him around the world watching, identifying and writing about birds. ${ }^{28}$

While these were individual motivations, they reflect the themes presented by many activists in the area. Women were also prominent in the advocacy of informal social activities on the Cooks River, as Tyrrell has noted, suggesting that such gatherings may have been particularly important for women, indicating a gendered relationship to the riverbanks. ${ }^{29}$ The LKBPC reflected all of these motives in its press statements and letters to council, as did the OFF newsletters of the time. Significantly, throughout their correspondence, the LKBPC used quotation marks to enclose the terms 'reclamation' and 'reclaim', pointing to their argument that this was not a legitimate concept. Rather, they argued that local and state governments should be acting to conserve all forms of natural vegetation, not artificially seeking to 'restore' to dry land something that had always been an area of interaction between land and water. This would allow, the campaigners argued, a more varied experience of recreation and learning for children and young people, rather than the uniformity and discipline of competitive sports. OFF echoed this view, which was the one Ruth Staples has remembered as one of her driving motivations. OFF argued:

Council proposes to use the final filled area in this case as a 'much needed recreation area.' No-one would deny that recreation areas are a must in any large centre of population. But must all recreation be formalised? City children today have very little opportunity to experience that affinity with natural things that is everyone's birthright and as the city grows, this opportunity shrinks ... It would be cheaper and more rewarding to care for the little natural bush we have left than to try to create a future substitute. ${ }^{30}$

28 The details of remembered motives are drawn from the interviews recorded with each: with Ruth on 27 May and 27 October 2005, and with David on 16 October 2019.

29 In the 1950s, Coleen Mary Webster, secretary of the Cooks River Valley Association, spoke up against plans for soccer stadiums for men in favour of quieter, 'passive' recreation places for families and women. Women were also notable in the campaigning against the development of Nanny Goat Hill near Wolli Creek and the extension of the airport at Botany Bay. Tyrrell, River Dreams, 163-64. 30 Editorial, OFF News, August 1974, 1-2, LKBPC Archive. 
It is notable, however, that of the many complex and often competitive interrelationships that ecology revealed in saline estuaries, it was the most anthropomorphic qualities of mangroves that were stressed. Mangroves were presented as nurturing the immature stages of species like fish, prawns and crabs as well as protecting saltmarsh and open spaces against increased siltation. From the wide range of ecological advice, it was this maternal role - as protective nurturers - that activists chose to present most commonly in their campaigns, as it was the characterisation most likely to attract public empathy and support. This is analogous to the choices of charismatic species (e.g. koalas, dolphins, whales and penguins) as emblems in environmental campaigns because such animals evoke emotional responses in human audiences, fostering approval for protective measures that affect a far wider ecosystem than the focal species. This selective approach, taking the most sympathetic from a far wider range of attributes, can be seen as an attempt to counter the long-established, deep-seated prejudices against mangroves that continued to be used to support reclamation.

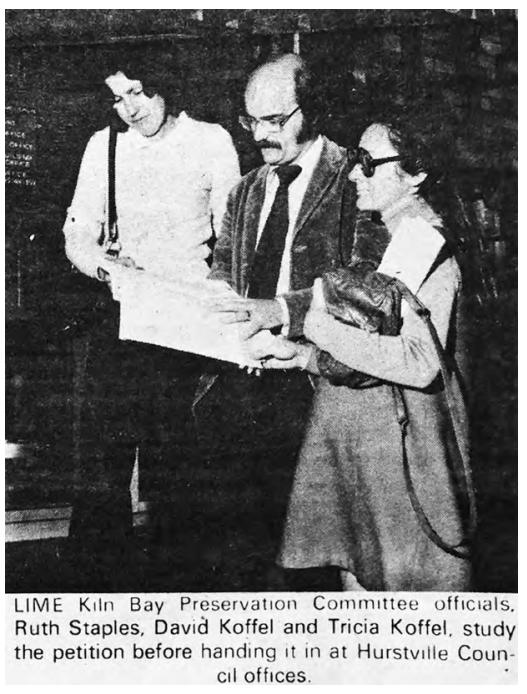

Figure 11.2: Lime Kiln Bay Preservation Committee founding activists Ruth Staples and Dave and Tricia Koffel.

St George Pictorial, 8 May 1974. Courtesy of Dave Koffel, LKBPC Archive.
Beyond their fears and interests, as well as their media strategies, the LKBPC, early in 1974, proposed alternatives to Hurstville Council, again taking their campaign beyond any NIMBY desire simply to move the problem somewhere else. They, like the OFF activists in the 1969 negotiations, recognised the difficulties councils were facing with the escalating volumes of solid waste being collected from homes and industries. From its first letter to Hurstville Council in December 1973, LKBPC called on the council to increase processing of the garbage it collected, not only through further technology but also, as a long-term solution, to initiate recycling - the separation and reprocessing of materials within the collected waste - no 
matter how expensive it might appear at first. ${ }^{31}$ Recycling was not an accepted practice in Australia at that time ${ }^{32}$ but the Lime Kiln Bay group persisted in spreading the idea both locally and more broadly among environmental activists.

Further, although sewage pollution was not their priority campaign focus, the group developed a plan for ongoing future management of the local sullage flows into these suburban waterways. First, from their very earliest meetings, they proposed that there be a pooling system created in the as yet 'un-reclaimed' eastern (Dairy Creek) arm of Lime Kiln Bay that would filter the run-off from the surrounding built-up areas before it flowed into the creek. Then they addressed - and organised - a system of rotating voluntary 'bush regenerators', another innovative approach developed only recently among nearby resident action groups in areas where bushland was at stake. This method of bank regeneration, one of minimal disturbance, became known as the 'Bradley method'. It involved painstaking, labour-intensive removal of invasive species (i.e. 'weeds') by hand, in small patches around healthy native plants in order to allow those native species to regenerate and regain their earlier distributions. The committee met with council in February 1975 to argue for both the bank regeneration proposal and the engineering strategy suggested by committee member Norm Tonkin for the tidal pooling system to filter run-off. ${ }^{33}$

Despite the hostile reaction they had received, the LKBPC sustained pressure on Hurstville Council, urging it to adopt the conciliatory approach that Bankstown had taken on the Little Salt Pan dispute, in which the council had not only abandoned its dumping plans but also had set up a consultative committee to give local residents a voice in future environmental planning. Strategically, however, drawing on the political experience of Koffel and others in the group, the Lime Kiln Bay group communicated with the state Labor Party, then in opposition but taking an active stand on environmental issues. While questions of land were legally in the hands of state governments, the federal Senate Select Committee had condemned the New South Wales Government's handling of its waterways in its pollution report and, after November

31 LKBPC to HMC, December 1973, included in Press Release 1, LKBPC Archive.

32 Waste Not, 'History of Waste', accessed 21 January 2021, www.wastenot.org.au. This is a Total Environment Centre project.

33 David Koffel, notes of the meeting, 28 February 1975, LKBPC Archive. 
1972, Labor was in power federally for the first time in decades. Labor had a reforming agenda - for Environment, under Minister Moss Cass, and for Urban Affairs, under Tom Uren. The Lime Kiln Bay group had strong support from the local member in state parliament, Frank Walker - a powerful activist on the left of the party as well as a highly respected local member - and he drew support from Pat Rogan, an ALP member from upstream who had supported the activists in the East Hills and Picnic Point areas. Even in opposition, Walker was able to bring the state Labor shadow minister Bob Carr out to the Georges River, highlighting the problems under the conservative Askin government but, even more importantly, to set the state ALP agenda on environmental reform as it campaigned for the next election. ${ }^{34}$

On 6 March 1974, the LKBPC wrote to the Municipal and Shire Council Employees' Union (MSCEU) to ask for their support in stopping the council's plans to dump rubbish and reclaim the wetlands of Lime Kiln Bay. Their letter listed their concerns about both loss of amenity and recreation facilities for all citizens of the area and the city, as well as the destruction threatened for the swamp and mangrove area. They explained further that they had major support from community members, with petitions signed, positive responses on door knocking, support from many local groups (e.g. the parents and citizen's organisations), endorsement from the federal member, Len Reynolds (ALP, member of the House of Representatives), as well as state members Frank Walker and others. Finally, they appealed for MSCEU support, saying:

If your members objected to the proposal of the Council, our committee believes that it would be extremely difficult for the Council to pursue its plans and that a unique area of the South Western Suburbs could be saved.

Dave Koffel signed the letter as committee secretary: 'Yours fraternally. ${ }^{35}$ The union never wrote back.

34 'NSW Pollution Laws No Deterrent to Big Business', National Times, 21-26 January 1974, 47-48; 'River Sets Labor's Strategy: Pollution Is Vote Clincher', St George Pictorial, 6 February 1974, 3; 'Pollution in Georges River "Alarming” - Wran: Mangroves Go', Leader, 20 February 1974, 11; 'Pollution ... Mangroves Go', Leader, 20 February 1974, 15.

35 LKBPC to MSCEU, 6 March 1974, LKBPC Archive. 
The Lime Kiln Bay campaigners also contacted the New South Wales BLF through its president, Jack Mundey, writing:

So far we have tried just about everything to stop the Council: publicity (within our local area); petitions; calls for an Environmental Impact Study (which has been ignored); and calls for the Council to reconsider the project (which it has promised to do, and 'deferred' at its last two meetings, etc, etc.

We have also asked the Municipal and Shire Council Employees' Union to object to the proposal, so making it extremely difficult for the Council to pursue its plans. However, although the Union did not even bother to reply to our requests (made 3 months ago) we know that our request was rejected unanimously by the union's executive.

Mr Mundey, can you advise of us anyone in that union to contact? ? $^{36}$

Jack Mundey wrote back supportively on 15 July 1974, suggesting they write to BLF Secretary Joe Owens, asking him to bring the matter before the union executive, where Mundey would support it. He offered to come to the preservation committee's proposed 'clean up' of the area to demonstrate his support and explained that he had made enquiries about the MSCEU, learning that 'this Union hasn't been active at all on conservation issues'. He suggested a formal letter to the New South Wales Branch and federal secretary of the MSCEU to see if that elicited any response; it did not. With no support forthcoming, the Lime Kiln Bay activists focused instead on the local government elections and did not make any further attempts to gain union support. ${ }^{37}$

Hurstville Council eventually, and grudgingly, produced the environmental impact assessment for which the Lime Kiln Bay committee had been asking. ${ }^{38}$ The joint report of the council engineer, E. Anderson, and the health surveyor, D. A. Webster, on the proposed reclamation was tabled before council in June. The report made it clear that the need for space for additional garbage disposal was the council's priority and had been planned for some years. Having reviewed the alternatives, including a shredder or incineration, the engineer and the health surveyor advised

\footnotetext{
36 LKBPC to NSW BLF, 15 June 1974, LKBPC Archive.

37 Jack Mundey for NSW BLF to LKBPC, 15 July 1974, LKBPC Archive.

38 'The Municipal Engineer and the Municipal Health Surveyor's Special Report, Incorporating a Study of the Reclamation of Lime Kiln Bay', 20 June 1974, LKBPC Archive.
} 
council that the reclamation of Lime Kiln Bay was the cheapest option. In addition, it would also enhance property values for neighbours by the expansion of the golf course.

Engineer Anderson drew on military aerial photographs from 1937, just as the earlier municipal engineer, Albert Brewer, had done in 1969. Brewer, however, had used emotive language, arguing that the expanding and 'foul mangrove swamp' was a 'noxious weed' and a 'cancerous growth' and so must be stopped. ${ }^{39}$ Anderson was more restrained, relying on scientific language and the evidence of figures from the quantified aerial photos to argue that from 1937 to 1974 , mangrove area had expanded from 4.5 acres to 24.5 acres. The phrase 'natural reclamation' was repeated several times, indicating the engineer's belief that siltation from upstream clearing was the cause of the mangrove expansion and would eventually lead to the mangroves' decline as they were starved of tidal flow. The council was just hastening the process by a few years. It planned to completely 'eliminate' the 'wetlands', which were 'undesirable because of their attraction to mosquitoes, snakes and rodents' and produced 'offensive odours'. The council's reclamation, the report continued, would also reduce the prevalence of spiders and other insects (as they were mangrove dwellers). The goal of this special report was clear from the title of Section 4, which was 'Advantages of Reclamation over other systems of Garbage Disposal'. This section then argued that the reclamation would be of:

Inestimatable [sic] value to the Community for the creation of sporting fields ... which are a necessity of paramount importance and, with the ever increasing requirements of the growing Community, difficulty is experienced in satisfying the needs..$^{40}$

The report confirmed the worst fears of the Lime Kiln Bay campaigners. After attending some acrimonious meetings with councillors, which just compounded the rejection they had met from the Municipal Employees' Union, the LKBPC threw itself into campaigning for the local government elections in September. Their flyers portrayed the area as 'bush', evoking all the complex symbolism of the 'bush' as the core of Australian identity in their call not to betray the nation: 'Don't Rubbish Our Bush' (see Figure 11.3).

39 F. N. Brewer, Hurstville Council Minutes, 6 March 1969, item 274, Hurstville Local Studies Archive, Georges River Council Libraries.

40 Ibid., 4. 

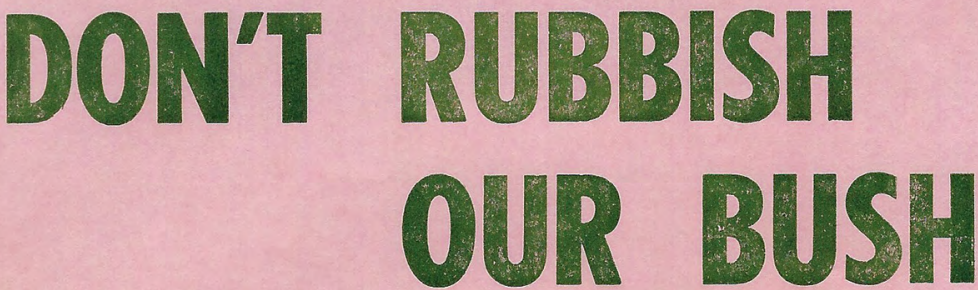

Hurstville Council plans to dump rubbish in Lime Kiln Bay next to Oatley Park.

\section{WE OPPOSE THIS BECAUSE -}

1 More than 100 varieties of birds and animals feed and breed in this part of the Georges River.

2 It will destroy a valuable bushland.

3 Hurstville Council should be trying to save their part of the Georges River - not fill it with rubbish.

4 The area has recognised educational value. School children visit the area.

\section{THE ALTERNATIVES :}

Recycle* glass, metal, paper and plastic - other councils do Exclude industrial tipping in the present tip to extend its life Incorporate the area in Oatley Park

* This could be a source of revenue

The Council has ignored our petition of 1200 signature.

\section{WHAT CAN WE DO NEXT?}

On September the 21 st. vote for the candidates who promise to preserve our unique bush.

If you can help our campaign contact $576797,5796775,5795356$

Issued by Lime Kiln Bay Preservation Committee

Authorised by J. Blacker, 17 Bay Road, Oatley

Printed by Acacia Press, 2 Acacia Street, Oatley

\section{Figure 11.3: LKBPC election flyer: 'Don't Rubbish Our Bush',}

\section{September 1974.}

LKBPC election flyer encouraging voters in the local election to 'vote for the candidates who promise to preserve our unique bush'. Courtesy of Dave Koffel, LKBPC Archive. 


\section{OATLEY IS OUR SUBURB}

IT IS THREATENED BY:

Home units. - Expressways. - Rubbish tips. -

Destruction of our river foreshores. - Rezoning. Increases in rates. - An oil refinery. -

Follution of our air and waterways.

\section{VOTE 1 DAVID THORP}

\section{OATLEY'S INDEPENDENT CANDIDATE WHO WILL WORK TO:}

1. Retain our foreshores and bushland.

2. Accept the recommendations of the Metropolitan Waste Disposal Authority to end tipping in Lime Kiln Bay.

3. Work for the recycling of metal glass and paper.

4. Complete the golf course and tennis courts.

5. Build a swimming pool and adventure playgrounds.

\section{YOUR VOTE IS VITAL}

On September 21st. carefully follow David Thorp's How-to-Vote Card.

Hurstville Municipal Elections. Peakhurst Ward.

Figure 11.4: 'Oatley is Our Suburb', David Thorp election flyer, September 1974.

Courtesy of Dave Koffel, LKBPC Archive. 
The group appealed to community members to see Lime Kiln Bay as their own, hoping they would want to defend it together, as a collective commitment. They were even able to obtain a page in the local Anglican Church newsletter, Span, in which they invited residents to 'take a walk and see for yourself'. They offered a map and an informative walking tour guide to build attachment and protectiveness. Rather than telling people what to think or how to vote, their approach was to encourage independent thinking, asking readers to have a look and make their own decision: 'Should it be destroyed or saved?'41

This energetic campaign was successful in wards close to the river in bringing more sympathetic councillors, like David Thorp and Julian Sheen, into the councils of both Hurstville and the adjoining Kogarah. They could not, however, mobilise enough votes in the wards away from the river to remove all the councillors who were committed to reclamations. After this election, the negotiations with the council were easier, but it was still not certain that the eastern arm of Lime Kiln Bay could be kept safe.

The campaigners had taken an active role in reaching out widely across the community throughout the year, so their work for the September election had extended this outreach even further. Yet, they had little knowledge of earlier movements. Just as Kevin Howard, the Bankstown health inspector had not known at all about the 1950s Picnic Point campaigners who had won the national park, despite sitting on the trust himself, so the Lime Kiln Bay committee knew nothing about the activists in their own area even in 1968 and 1969, let alone those who might have come before. It was only later in the campaigning in which Dave Koffel was involved that the petition written in 1968 came to light. ${ }^{42}$

While the LKBPC had not been aware of earlier movements, they had learnt more about the council's plans to 'reclaim' all the bays under its control. The committee had heard informally that council had applied for permission as early as 1971 to carry out the work. This application had demonstrated that council's goal was to fill in not just Lime Kiln Bay but Jewfish and Gungah bays too. But Hurstville Council had refused to release these plans.

41 Span, St Peter's Anglican News, Mortdale, August 1974, vol. 19, no. 6, 4, LKBPC Archive.

42 Koffel, interview. 
In numerous community venues from January 1974, LKBPC activists explained that the council intended to fill all the bays. But the community simply did not believe them. Most local residents saw themselves as relatively economically well-off and correspondingly politically powerful. As Dave recalled:

Well, people just said - 'Oh they're not going to fill in Edith Bay, this is Lugarno!' Or 'They're not going to fill in Jewfish Bay. We live on Landsdowne Parade, you know!' The class system actually cut in, you know? And 'We're silvertails, no one's going to put rubbish in our bays'. This is what they would say to you! $!^{43}$

In 1976 the ALP came to power in New South Wales under Neville Wran and the supportive local member Frank Walker became minister for lands. He ordered Hurstville Council to release its plans for the bays, which it finally did in May 1976. These plans revealed that, indeed, the council did plan to fill in all the bays along the northern shore. There was immediate community uproar and an avalanche of support for the campaigners trying to stop the reclamations. In August 1976, a public meeting formed the Preserve Oatley West Resident Action Group (POW) to which the LKBPC was happy to affiliate. Together they collected 4,300 signatures on a petition to state parliament. Hurstville Council continued to raise the possibility of allowing the bays to be 'naturally reclaimed' with siltation - after which the council would then build playing fields! The Wran government assured POW and the LKBPC that no government approval would ever be issued, taking the plans effectively off the table permanently. Dave Koffel's summary of the campaign in 2005 for Alan Fairley's book ended cautiously with: 'It would appear that finally we had won!'44 
This text is taken from Georges River Blues: Swamps, Mangroves and Resident Action, 1945-1980, by Heather Goodall, published 2022, The Australian National University, Canberra, Australia.

doi.org/10.22459/GRB.2021.11 